MARIA N N GÖRMAN

\title{
Influences from the Huns on Scandinavian Sacrificial Customs during 300-500 AD
}

\section{Introduction}

Votive offerings may be our main source of knowledge concerning the religion of the Iron Age before the Vikings. By the term votive offering I refer to objects placed in the ground, mainly in lakes and peat-bogs, with a sacrificial intention. Peat-bogs, as well as springs and lakes, were in prehistoric times used as holy places for whole districts, often for long periods of time. Sacrificial weapon finds are an important category of votive offerings from the Iron Age. Objects typical of this group of finds are weapons and other military equipment, but they also contain personal items, household utensils, tools, boats, carriages, and horse utensils. Many of these objects carry marks of combat, but in addition they have been deliberately destroyed, cut into pieces, and sometimes even ravaged by fire. The purpose of this violent devastation is generally considered to have been the intention to make everyday use impossible and to consecrate them to the gods (see Görman 1987: $131 \mathrm{f}$. and the references there).

In southern Sweden, Denmark, and the southern part of Schleswig a number of similar weapon finds have been made, generally characterized as war-booty offerings. The find from Hjortspring in Denmark, dated to the third or second century B.C., is the oldest of these war booty sacrifices. Most of them were, however, deposited from the end of the second century to the beginning of the sixth century AD. ${ }^{1}$

A number of our comprehensive finds of weapons were already excavated and the results published last century by Conrad Engelhardt. He was responsible for the excavations of Torsbjerg (1863), Nydam (1865), Kragehul (1867) and Vimose (1869). In 1865, soon after the publication

1 Concerning the dating of the Hjortspring find see Jensen 1982: 258; concerning the other finds see Fabech 1989: 108. 
of the hoards from Torsbjerg and Nydam, J. J. A. Worsaae asked in his publication Om Slesvigs eller Sønderjyllands Oldtidsminder if the elaborate buryings of military objects could perhaps have been made according to specific religious customs, setting the victors under an obligation to sacrifice the captured animals, as well as part of the other booty, to the gods after the battle, among other things by depositing it in holy lakes or nearby peat-bogs. ("... om ikke de omhyggelige Nedlægninger netop av krigeriske Gjenstande i Moserne kunne tænkes at være skete ifölge bestemte religiöse Skikke, som böd de Seirende, efter Slagene baade at offre de fangne Dyr og en Deel af det övrige Bytte til Guderne, bl.A. ved at nedsænke det i hellige Söer eller nuværende Moser" Worsaae 1865: 57).

The number of finds has considerably increased during the past 35 years through the comprehensive excavations at Ejsbøl (Ørsnes 1988) and Illerup (Ilkjær and Lønstrup 1983), both on Jylland, and at Skedemosse on Öland (Hagberg 1967). These new finds are in general considered to support the suggestion of Worsaae to interpret the extensive burying of war booty as sacrifices to the gods. A full description of the sacrificial weapon hoards which could give us answers to specific questions has been missing for a long time. But recently the Danish archaeologist Charlotte Fabech published a study of 38 Danish and Swedish finds, traditionally interpreted as sacrifices of war booty, which she examines with regard to their contents, the ways the objects have been treated, the different ways of depositing, and the environments. In her investigation she draws the conclusion that the finds from Sösdala and Fulltofta in Skåne and from Vennebo in Västergötland should not be interpreted as sacrificial weapon hoards, but rather as burial offerings. She writes that they are remains of a death-cult which was part of the funeral ceremonies of some areas in southern Sweden ("... efterladenskaber efter en dødekult, der var en del av visse sydsvenske områders gravlægningsceremoniel" Fabech 1989: 109).

In her discussion Fabech calls attention to the fact that this group of finds has counterparts in Eastern and Central Europe. The interpretation of some new finds from the Huns, such as Pannonhalma, together with current reinterpretations of some older finds, such as Szeged-Nagyszéksós, give us a good idea of the funeral rites of the Huns. István Bóna describes them as "Scheiterhaufenfund" (Bóna 1979: 297 ff.). The deposits from Sösdala, Fulltofta and Vennebo are contemporary with some of these finds from the Huns. According to Fabech they are to be interpreted in the same way as these, i.e. as "ligfærdsofre", reflecting a Hunnish tradition. She says further, without developing this thought, that people in Scandinavia, who 
had close relations to the Huns, may have assimilated their nomadic lifestyle as well as certain myths and rites. This would, however, not have to imply that they had picked up the ideas behind these traditions and practices (Fabech 1989: 113 f.).

Another interesting group of sacrificial finds consists of horses, sacrificed in a specific way. These sacrifices, too, seem to be connected to eastern cultures. During certain offerings where horses were sacrificed, the participants preserved the animals' heads, feet and tails. Horse sacrifices of this type are known from a few Danish and one Swedish peat-bog, from the Sorte Muld site on Bornholm, and possibly from a few Danish graves. Similar finds have been made on the Continent, and the Huns have been conceived as the mediators of this form of horse sacrifice (Klindt-Jensen 1959: $51 \mathrm{ff}$.).

In my opinion there is a connection between these two groups of finds. The hoards from Sösdala, Fulltofta and Vennebo on one hand and the sacrificial finds from southern Scandinavia, consisting of crania, extremity bones, and caudal vertebrae from horses on the other hand, share the same cultural and religious background. They can both be connected to the Huns. Both belong to the same time, i.e. the late Roman Iron Age and the Migration Period. Thus, burial sacrifices and horse sacrifices can both be regarded as indications that rites, influenced by equestrian nomads from the east, were practised in southern Scandinavia during this time, i.e. the fourth to sixth centuries AD. When people have assimilated and exercised religious rites with such specific traits, it indicates, in my opinion, that they have also picked up the underlying ideas. They need not have accepted the religious conceptions of the Huns in full, but at least to such an extent that it was meaningful to perform similar rites. In this article I intend to investigate the form and content of these religious practices in the surroundings from which they emanated, in order to obtain an impression of their meaning in the new surroundings where they were executed.

\section{The Huns and their Influence in Europe}

The Huns were horsemen of Altaic origin who played an important role in the history of Europe during the fourth and fifth centuries AD. It is under debate whether they can also be identified with Hsiung-nu, who attacked China during the centuries B.C., and who is well known through Chinese 
annals. The Huns spread westwards from the steppes of central Asia, and around $370 \mathrm{AD}$ they conquered the Ostrogothic kingdom of Ermanarik, situated north of the Black Sea.

Thus, the realm of the Huns grew up in the eastern parts of Central Europe, and its central area was situated on the plains of Hungary. They reached the height of their power under the command of Attila, who reigned between 434 and $454 \mathrm{AD}$. During this period their sphere of power stretched from the Volga to the Rhine and from the Danube to the Baltic. (The realm of the Huns is shown in figure 2.) Many Germanic peoples, such as the Ostrogoths and the Gepids, were tributary people to the Huns. Even the powerful Byzantine empire paid tribute to them at times. The attacks of Attila towards the west became more and more intense, and in 451 the Huns, together with the Visigoths and the Franks, fought a great battle against the Romans and their allies in the vicinity of Troyes in Champagne. On this occasion Attila and his auxiliary troops were defeated. After the death of Attila in 453 his mighty empire soon fell into pieces.

Our knowledge of the Huns is relatively good, as we have access to archaeological finds as well as written sources. The Huns themselves have not left any written documents, but they appear in contemporary historical works produced within the boundaries of the Roman empire. The classical authors could follow the Huns from around 370 until 469, when they ceased to act as organized units. Particularly valuable is the section on the Huns in the Roman history of 31 volumes written by Ammianus Marcellinus, which covers the period 98-378 AD and which was finished around 390. Other important works are the writings of Priscus of Panium, of which only fragments have been preserved. Priscus himself visited the court of king Attila in 448 and gave an eye witness report of what happened there. Parts of the account of Priscus have been preserved in the so called Getica, written by the Ostrogothic historiographer Jordanes. This work, which dates from the middle of the sixth century, rests on fragments from Priscus as well as extracts from Cassiodoros' lost history of the Goths. ${ }^{2}$

A number of different archaeological finds in Europe give evidence of eastern influences during the period c. 150-600 AD. The influences during the latter part of this period originate to a great extent from the Huns. This applies, for instance, to the deformation of skulls, metal mirrors,

\footnotetext{
2 A detailed historical account as well as a discussion of the sources is given by Maenchen-Helfen 1973; cf. Thompson 1948.
} 
earrings made of round thread, cauldrons and diadems of eastern type, sword amulets, long two-edged swords, short one-edged swords, bows with bone mountings, riding whips (nagaika), horse equipment, as well as horse sacrifices with the preservation of head, feet and tail. ${ }^{3}$

The deformation of skulls, mentioned above, is especially striking. It meant an extension of the skull which was accomplished in early infancy. (Figure 1) This custom, which was well known among the Huns, became the height of fashion among different Germanic tribes during the glorious days of the Huns. Artificial deformation of the skull was executed on both men and women among the Ostrogoths and the Gepids. Among the Lombards and the Burgundians this custom seems to have comprised women only. There are proofs of this habit as far north as the central parts of Germany and eastern France. (Figure 2) When the reign of Attila fell apart, this practise went out of use among the Germanic peoples (Werner 1956: 5 ff.; Klindt-Jensen 1959: 51 ff.).

\section{Burial Sacrifices?}

\section{The Sösdala Find}

In 1929 some workers digging gravel at Sösdala in N. Mellby in Skåne found a treasure which they shared among themselves. In spite of this, the main part of the treasure was saved through a resolute act of intervention by two private persons. One of these, the elementary-school teacher C. Mellton, carried out a supplementary investigation on the site of the find and found some additional objects. In the following year a few more finds were made. The finds from 1929-1930, usually called Sösdala I, comprise c. 250 objects. At a new digging of gravel in 1961 around thirty more objects were found c. $60 \mathrm{~m}$ east of the site of the earlier finds (Sösdala II).

No systematic archaeological investigation of the Sösdala area has yet been accomplished, although a few small investigations have been made. The sites of the finds are situated on the top of a big gravel ridge in the close vicinity of the cremation grave-field at Vätteryd. The whole area is greatly affected by the gravel digging, among other things for the purpose of road construction, which has been going on there. It is also estimated

3 Concerning eastern influences see Wermer 1956; Klindt-Jensen 1957; Klindt-Jensen 1959; Bóna 1979. 

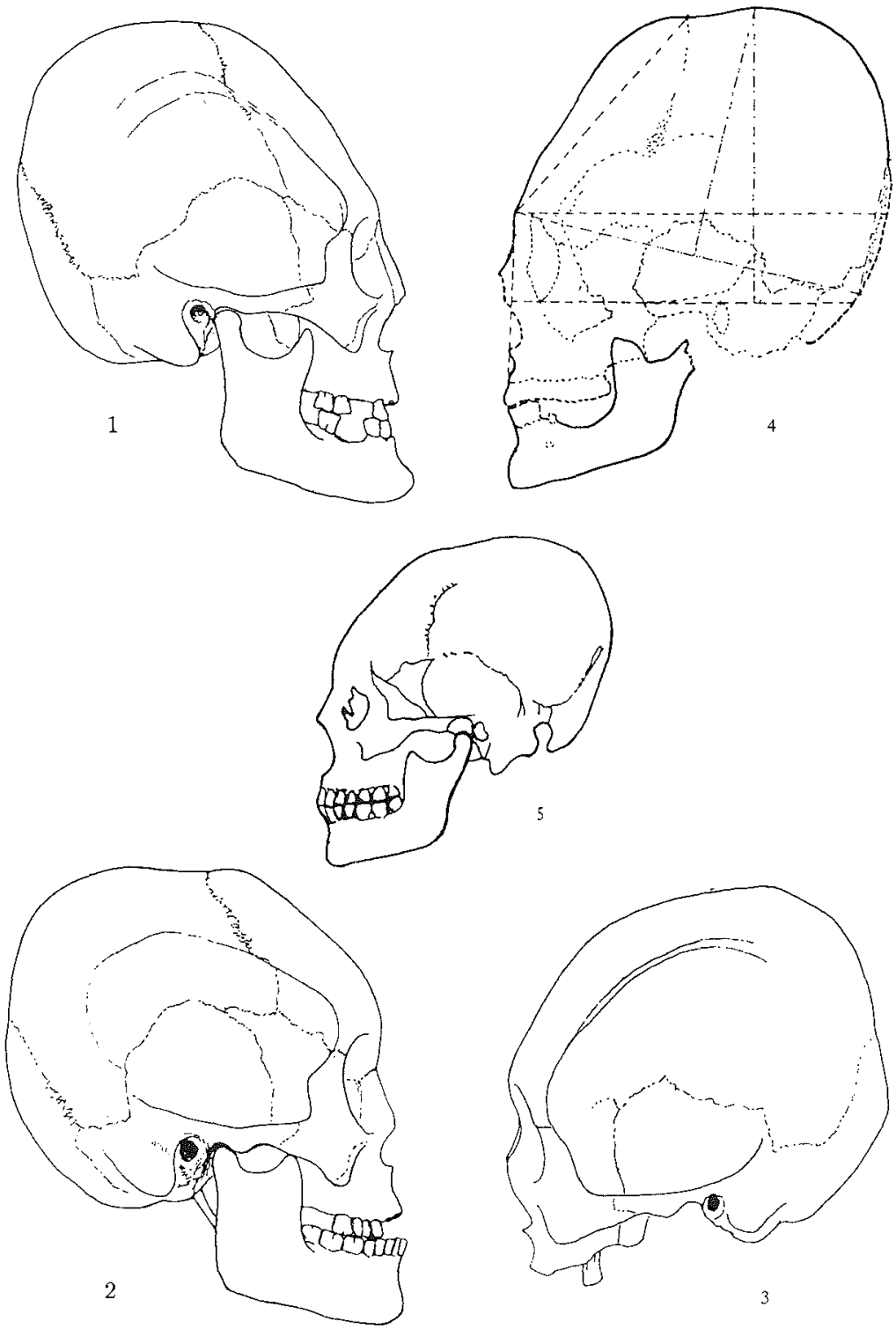

Figure 1. Artificial deformation of the skull became the height of fashion during the Migration Period among the Germanic peoples who were under the influence of the Huns. This picture shows extended crania, originating from graves at Tsjung-Tipä in Talas, Khazakstan (1, 2, 3), Obermüllern, Sachsen (4) and Ingersleben, Thüringen (5) (Werner 1956/2: Tafel 33). 


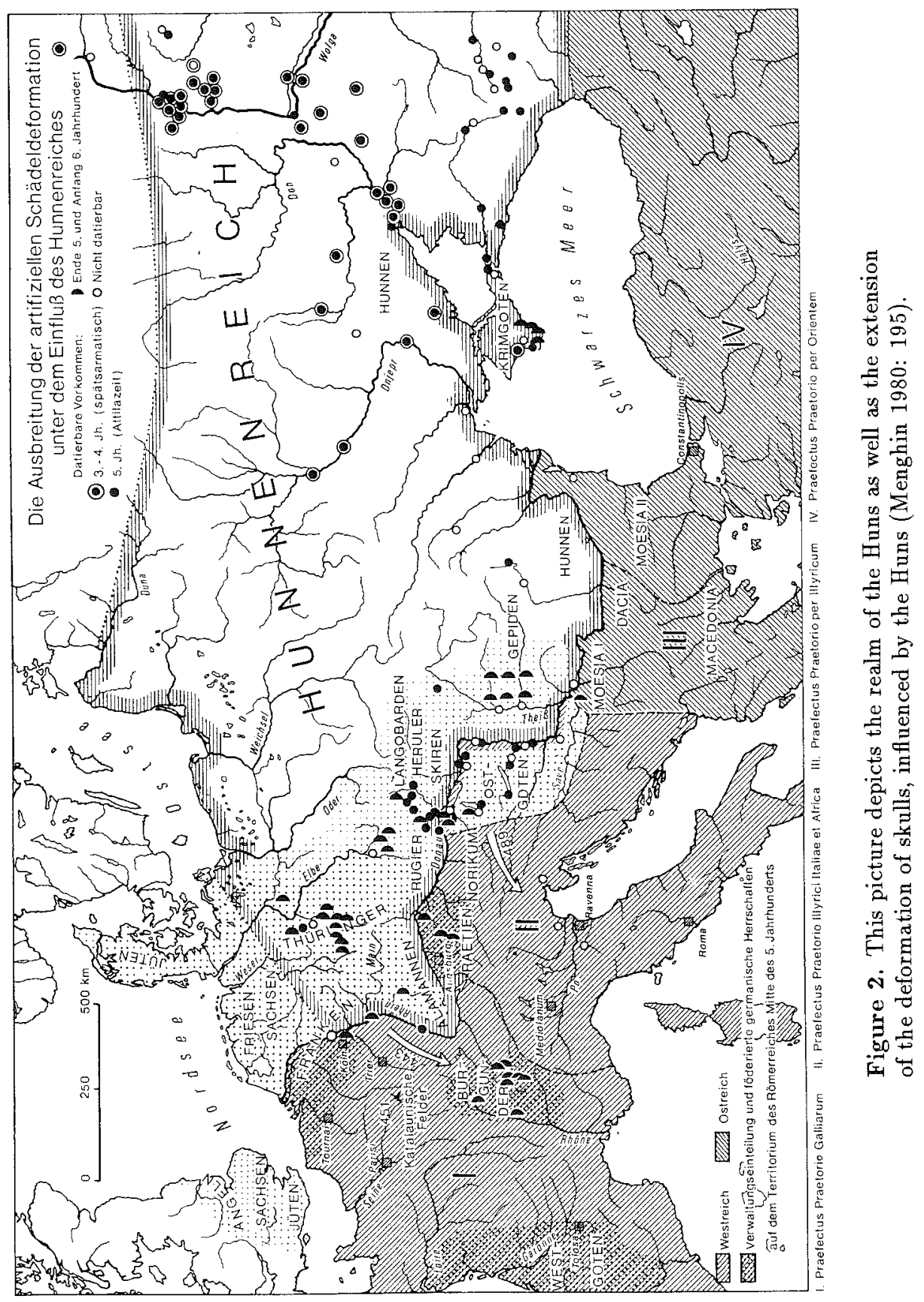


that parts of the Vätteryd grave-field, situated nearby, have been lost through road construction (Strömberg 1961/1: $62 \mathrm{f}$.).

The Sösdala hoard consists of horse mountings of silver and bronze belonging to at least five headstalls and five saddles. Some time during the first part of the fifth century AD they were laid down in five heaps, only spit deep, at the top of the ridge. Four of the heaps were situated within an area of $12 \mathrm{~m}^{2}$. Before deposition the objects were sorted according to function and material and were exposed to deliberate damage. In one of the heaps a headstall of silver was placed, in another one of bronze, and in the remaining three there are bronze mountings for at least five horse saddles. The heaps were then covered with earth and/or a layer of stones the size of heads. ${ }^{4}$

In 1931 the question was raised as to whether the finds from Sösdala should be regarded as sacrificial weapon hoards (Norberg 1931: 111). Hagberg, who treats Sösdala I and II in connection with his discussion of the interpretation of the finds from Skedemosse, does not take a definite stand on this question. He conceives the group of finds from Sösdala as pars-pro-toto sacrifices, devoted to a god with a special connection to the horse (Hagberg 1967/2: 70). Charlotte Fabech, who has recently made a thorough investigation of most of the sacrificial weapon finds, repudiates the interpretation of the Sösdala finds as sacrifices of war booty. She connects them with the finds from Fulltofta in Skåne and Vennebo in Västergötland, and she further combines this group of deposits with a number of finds from Eastern and Central Europe, which have been interpreted as Hunnish burial sacrifices (Fabech 1987: $266 \mathrm{ff}$.).

\section{The Fulltofta Find}

In Fulltofta, situated only $15 \mathrm{~km}$ from Sösdala, a find of horse equipment was made in 1896. The objects are reported to have been lying c. $90 \mathrm{~cm}$ below the surface of the earth. As in Sösdala, the site of the hoard was on the top of a gravel ridge, about two $\mathrm{km}$ from Östra Ringsjön. A few hundred metres from the place where the find was made, two not yet investigated grave monuments are located, and two $\mathrm{km}$ farther away is a big grave-field, Nunnäs, from the Iron Age. This burial place has the same character as the Vätteryd grave-field in Sösdala.

The Fulltofta find consists of 23 bronze mountings belonging to at least one saddle and one headstall. Two of these mountings are more magnificent than the others and have gilded silver coatings. Some of

4 Concerning the Sösdala finds see Fabech 1987: $103 \mathrm{ff}$. 
them carry traces of intentional damage. Just like Sösdala I and II the objects from Fulltofta belong to the first part of the fifth century AD. ${ }^{5}$

\section{The Vennebo Find}

The information on the find from Vennebo in Roasjö in Västergötland is less exhaustive than the two cases discussed above. The objects are reported to have been found in the same place, but on three different occasions, during ground work in 1874. It is unclear whether the deposit was made in a peat-bog or in ordinary soil. This find, too, consists of horse equipment. It contains slightly more than 40 silver and bronze mountings, belonging to at least four headstalls, two saddles and one harness. Most of the mountings were deliber ately damaged before being laid in the ground. This hoard can be dated to the first part of the fifth century AD. Thus it is contemporary with the finds from Sösdala and Fulltofta. ${ }^{6}$

\section{Common Traits in the three Finds}

With some hesitation, because of the incomplete information, Fabech attributes the Vennebo find to the same group as Sösdala I and II and Fulltofta. This group is characterized by the following traits: The content was made up of precious saddles and harness. In several cases the objects show sign of having been subjected to deliberate damage. The mountings are broken apart and distorted. The horse equipment was laid in gravel ridges close to lakes and peat-bogs, where it was placed in small heaps just below ground level. The heaps contain no bones of animals or men. In the cases of Sösdala I and II and Fulltofta, the graves found within a distance of 100-500 $\mathrm{m}$ are probably contemporary. All of these finds can be dated to 400-450 AD (Fabech 1987: 266 f.; Fabech 1989: 113).

\section{Similar Finds on the Continent}

The three finds mentioned above are the only ones of this kind known at present in Scandinavia, but there are counterparts in Eastern and Central Europe. These hoards contain splendidly ornamented saddle and harness equipment in silver and gold, dresses decorated in gold, weapons, such as swords, daggers, bows, arrows, and bronze cauldrons. Often the weapons are ornamented in gold, too. Some objects were subjected to deliberate damage. They were folded together or torn to pieces and sometimes even

\footnotetext{
5 Concerning the Fulltofta find see Fabech 1987: $132 \mathrm{f}$.

6 Concerning the Vennebo find see Fabech 1987: $84 \mathrm{f}$.
} 
damaged by fire. They were deposited in the ground in heaps at a small depth. No traces of human bones, burned or unburned, have been found in the heaps.

Thus, there are several striking similarities between the two groups of finds. The following common traits can be distinguished: In both cases the hoards contain magnificent saddle and harness equipment and weapons, which have been subjected to damage and deposited in shallow pits close to graves. The finds on the Continent date from the end of the fourth century to the middle of the fifth century, while the Scandinavian finds can be dated to the first part of the fifth century (Fabech 1987: 272).

The recent finds at Zovtnev Velkotokmac in the Ukraine and Pokrovsk in southern Russia are examples of deposits of this type from Eastern Europe. István Bóna has discussed these finds. He argues that they give us knowledge of the rites of the Huns in connection with interments. He claims that research until now has failed to take these rites into account when interpreting the finds, and he claims that they can even contribute to the understanding of older finds, such as those from Jendrzychowice in Silesia and Szeged-Nagyszéksós on the Hungarian puszta. (In the vicinity of the last of these places, Ruga, Bleda and Attila are considered to have had their principal headquarters.) Many earlier hoards with incomplete documentation have been interpreted as grave finds. According to Bóna they should rather be interpreted as "Scheiterhaufenfund". Bóna points out that analogous ritual customs have been documented, for instance among the Avars and Turkish tribes around a hundred years later. Among these people the dead man was buried dressed in expensive clothes and together with his personal items. Thereafter a meal was eaten, consisting of one of the dead man's horses. The remains of the horse were placed on a pyre, together with weapons and horse equipment. In that connection the objects were often exposed to deliberate damage, for instance by being broken apart. After that the burned gifts were buried together with the unburned splendid outfit close to the ground level and not far from the grave (Bóna 1979: $310 \mathrm{ff}$.).

Fabech has noted the interpretation of Bóna and convincingly argued that the finds from Sösdala, Fulltofta, and probably even Vennebo, should be understood as sacrifices in connection with burials, by analogy with the finds from the Huns. I think Fabech is right in her interpretation of these deposits from southern Sweden. In my opinion the similarities between these and the hoards from the Continent are best explained by the hypothesis that the people who deposited the finds in Sösdala, Fulltofta, and Vennebo had ideas of death, funeral, and the life to come which were 
influenced by the ideas of the Huns. Hence it is interesting to investigate whether further information can be obtained on the behaviour of the Huns and their thoughts on the problems in question.

\section{Written Sources Concerning the Rites of the Huns at Death and Burial}

The ceremonies among the Huns in connection with death and burial are well known through various ancient authors. Priscus' Fragment No. 23 describes the death and funeral of Attila. This account also appears in Jordanes' Getica. In the Armenian chronicle Patmuticiwn Aluaniç, ascribed to Movsēs Dasxurançi, who is sometimes called Movsēs Kalankatuaçi, there is a very vivid description of a strava, i.e. a funeral feast, among the Huns in Caucasus in the beginning of the seventh century AD. Here I give both descriptions, starting with the account of Jordanes of the events after the death of Attila. Jordanes reports:

tunc, ut gentis illius mos est, crinium parte truncata informes facies cavis turpavere vulneribus, ut proeliator eximius non femineis lamentationibus et lacrimis, sed sanguine lugeretur virile. ...

cuius manes quibus a sua gente honoratae sunt, pauca de multis dicere non omittamus. in mediis si quidem campis et intra tenturia sirica cadavere conlocato spectaculum admirandum et sollemniter exhibetur. nam de tota gente Hunnorum lectissimi equites in eo loco, quo erat positus, in modum circensium cursibus ambientes, facta eius cantu funereo tali ordine referebant.

"praecipuus Hunnorum rex Attila, patre genitus Mundzuco, fortissimarum gentium dominus, qui inaudita ante se potentia solus Scythica et Germanica regna possedit nec
Then, as is the custom of that race, they plucked out the hair of their heads and made their faces hideous with deep wounds, that the renowned warrior might be mourned, not by effeminate wailings and tears, but by the blood of men. ...

We shall not omit to say a few words about the many ways in which his shade was honoured by his race. His body was placed in the midst of a plain and lay in state in a silken tent as a sight for men's admiration. The best horsemen of the entire tribe of the Huns rode around in circles, after the manner of circus games, in the place to which he had been brought and told of his deeds in a funeral dirge in the following manner:

"The chief of the Huns, King Attila, born of his sire Mundiuch, lord of bravest tribes, sole possessor of the Scythian and German realms -- powers unknown before - captured cities and terrified 
non utraque Romani urbis imperia captis civitatibus terruit et, ne praedae reliqua subderentur, placatus praecibus annuum vectigal accepit: cumque haec omnia proventu felicitatis egerit, non vulnere hostium, non fraude suorum, sed gente incolume inter gaudia laetus sine sensu doloris occubuit. quis ergo hunc exitum putet, quem nullus aestimat vindicandum?"

postquam talibus lamentis est defletus, stravam super tumulum eius quam appellant ipsi ingenti commessatione concelebrant, et contraria invicem sibi copulantes luctu funereo mixto gaudio explicabant, noctuque secreto cadaver terra reconditum copercula primum auro, secundum argento, tertium ferri rigore communiunt, significantes tali argumento potentissimo regi omnia convenisse: ferrum, quod gentes edomuit, aurum et argentum, quod ornatum rei publicae utriusque acceperit. addunt arma hostium caedibus adquisita, faleras vario gemmarum fulgore praetiosas et diversi generis insignia, quibus colitur aulicum decus. et, ut tantis divitiis humana curiositas arceretur, operi deputatos detestabili mercede trucidarunt, emersitque momentanea mors sepelientibus cum sepulto. (Jordanes 1882: XLIX, 255-258) both empires of the Roman world and, appeased by their prayers, took annual tribute to save the rest from plunder. And when he had accomplished all this by the favor of fortune, he fell, not by wound of the foe, nor by treachery of friends, but in the midst of his nation at peace, happy in his joy and without sense of pain. Who can rate this as death, when none believes it calls for vengeance?"

When they had mourned him with such lamentations, a strava, as they called it, was celebrated over his tomb with great revelling. They gave way in turn to the extremes of feeling and displayed funeral grief alternating with joy. Then in the secrecy of night they buried his body in the earth. They bound his coffins, the first with gold, the second with silver and the third with the strength of iron, showing by such means that these three things suited the mightiest of kings; iron because he subdued the nations, gold and silver because he received the honors of both empires. They also added the arms of foemen won in the fight, trappings of rare worth, sparkling with various gems, and ornaments of all sorts whereby princely state is maintained. And that so great riches might be kept from human curiosity, they slew those appointed to the work - a dreadful pay for their labor; and thus sudden death was the lot of those who buried him as well as of him who was buried.

(Translation by Charles C. Mierow)

Movsēs Dasxurançi likewise reports in Patmuticiwn Ałuanic how the Huns caused themselves deep wounds in the cheeks and limbs as a sign of grief. Here follows his account of a strava.

Possessing completely anarchical minds they stumble into every sort of error, beating drums and whistling over corpses, inflicting bloody sabre and dagger cuts on the cheek and limbs, and engaging naked in sword fights - $O$ hellish sight - at the graves, man against man and troop against troop, all stripped for battle. Numerous groups wrestled with each other and in the orgy performed 
swift gallops on horseback, wheeling this way and that. Some were occupied in weeping and wailing, others in a game of diabolical fury. They played their games and danced their dances with obscene acts, sunk in benighted filth and deprived of the light of the Creator. (Dasxurançi 1961: Ch. 40)

Jordanes' description of the ceremonies at the death and funeral of Attila in 453 share several traits with the account of Movsēs Dasxurançi of the burial rites of the Huns in the seventh century. They both mention the self-inflicted wounds of the participants, the abrupt changes of mood, and the furious rides. Jordanes says that those who had buried the king were killed in order to prevent plundering. Priscus may have misinterpreted this. It may have been a matter of human sacrifice. Furthermore, Movsēs mentions several specific elements, such as sword fighting, wrestling, and dancing, while Jordanes only writes about a drinking bout. In the report of Movsēs Dasxurançi the strava is characterized by an almost ecstatic and orgiastic atmosphere. Precisely this quality could perhaps explain the repudiation of the funeral rites of the Huns, which is expressed in another context in the Armenian chronicle. The Hunnish chieftain Alp ${ }^{c}$ Ilut ${ }^{c} u e \bar{r}$ is said to have especially underlined three things after having been converted to Christianity. In chapter 41 it is said:

Little by little he strove to abolish the frenzied laments for the dead and the bewitched swordfights, considering the religion of his fathers abominable and unclean, and to destroy the altars of Aspandiat and sacrifices to other false gods in favour of the worship of the living God ... (Dasxurançi 1961: Ch. 41)

As is evident, the repudiation has first of all the burial rites in view. Only then does the text refer to the cult of Aspandiat and other false gods.

Priscus, Jordanes, and Movsēs Dasxurançi all describe what could take place at the funerals of important leaders among the Huns on the Continent. The archaeological finds give us reason to believe that feasts of a similar form and atmosphere were also performed at Sösdala, Fulltofta and Vennebo.

\section{Horse Sacrifices}

Finds from Southern Scandinavia Containing Crania, Extremity Bones, and Caudal Vertebrae from Horses

Another group of sacrificial deposits which seems to have been influenced by equestrian nomads from the east consists of horse sacrifices where certain parts of the horses have been preserved. Several finds of this kind 
have been made in Denmark and southern Sweden. Shortly after 1950 Ole Klindt-Jensen made a coherent account of all the known deposits of crania, extremity bones, and caudal vertebrae from horses. He also discussed the context in which these horse sacrifices were executed ${ }^{7}$.

During the excavation of the abundant Sorte Muld site on Bornholm a hollow was found in the ground, $80 \times 85 \mathrm{~cm}$ wide and $18 \mathrm{~cm}$ deep, close to one of the houses. It contained the cranium of a horse and the lower parts of the legs of a horse, which had been cut off. (Figure 3) The cavity also contained a few vertebrae and some fragments of clay vessels. The bones were not split for marrow or gnawed by dogs, which is very unusual for bones found in a site. The cavity is contemporary with the houses in Sorte Muld and belongs to the Migration Period, probably around $500 \mathrm{AD}$. Klindt-Jensen interprets the bones as the remains of a horse sacrifice (Klindt-Jensen 1957: 83 ff.; Klindt-Jensen 1959: 56).

Other finds with the same combination of bones, i.e. crania and extremity bones from horses, have been made in a number of Danish peat-bogs and on Swedish territory. Sometimes the tongue has been cut out and the tail has been put into the animal's mouth. The biggest find originates from Valmosen at Rislev on Sjælland. It contains as many as 11 pairs of horse feet, and a slightly smaller number of crania. The skulls bear marked traces of strokes, which shows that the animals were put to death by a stroke on the forehead. The remains were assembled within an area of $9 \times 9.5 \mathrm{~m}$. Bones from two human beings and from some other animals were also found there. The humans may have been killed by hanging, as no cutting traces were found. Unlike the horses, the other animals were represented by the main parts of their skeletons, and the bones were often split for marrow. In the peat-bog a number of wooden stakes and scattered stones were also found. The find is dated to c. 300-400 AD (Klindt-Jensen 1957: $83 \mathrm{f}$.).

We know a few further finds of the same type from peat-bogs on Jylland, Sjælland and Lolland, as well as from Skedemosse on Öland. The combination of crania, extremity bones, and in some cases caudal vertebrae from horses is the same. ${ }^{8}$ Perhaps we can find remains of the same combination of horses' crania and bones in the deposits from a cavity close to the abundant grave at Varpelev on Sjælland, which originates from the late Roman Iron Age, and from a cremation grave on southern Bornholm from the late Iron Age, i.e. after 400 AD (Klindt-Jensen 1957: 84).

\footnotetext{
7 See above all Klindt-Jensen 1957: $83 \mathrm{ff}$., but also Klindt-Jensen 1959: $51 \mathrm{ff}$.

${ }^{8}$ Concerning Skedemosse see Hagberg 1964: 226; Hagberg 1967: 82; concerning the Danish peat-bogs see Klindt-Jensen 1957: 294.
} 


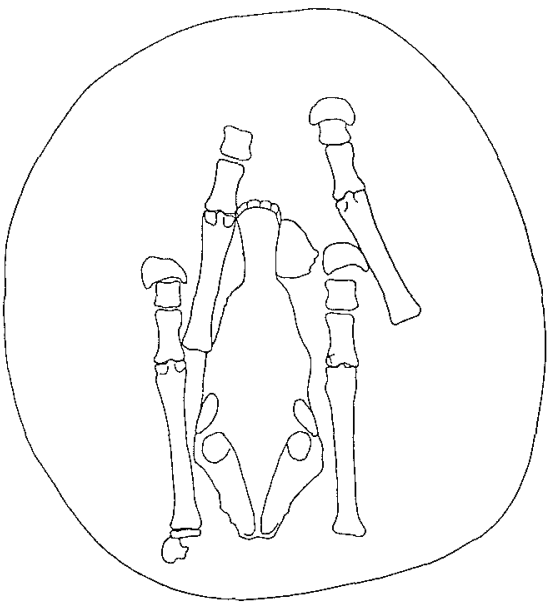

Figure 3. A cavity from the Sorte Muld site on Bomholm, containing a cranium and extremity bones from a horse (Klindt-Jensen 1957: 83).

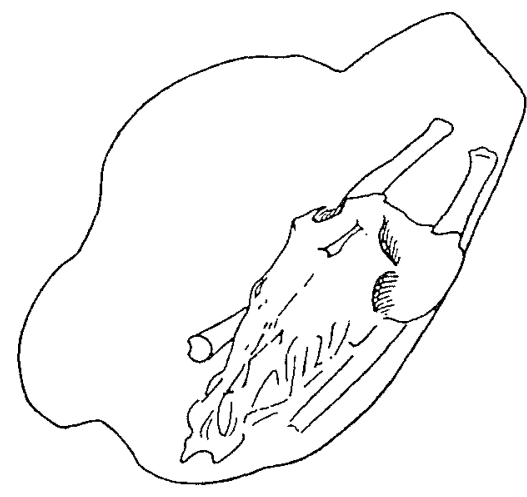

Figure 4. A cavity containing a cranium and the feet of a horse, from the Bajtal-Tschapkan grave field in northern Caucasus (Klindt-Jensen 1959:55).

Thus, we can certify that the habit of laying down crania and extremity bones of horses in cavities, peat-bogs, and perhaps even in graves, occurred during a limited period of the Iron Age, but on the other hand it seems to have been rather widely spread. Evidence of this custom can be found from the latter part of the Roman Iron Age, and it seems to have disappeared before the Viking Age (Klindt-Jensen 1957: 84). Only horses were subjected to this peculiar ritual treatment. Thus, the underlying ideas seem to have been particularly tied to the horse.

\section{Similar Finds on the Continent}

Analogues to the hoards from southern Scandinavia are known from Central Europe and from the southern parts of Eastern Europe. I would like to exemplify this by mentioning a grave in Leuna in central Germany. This grave is especially interesting, as its content makes it possible to date the grave to 200-400 AD. Close to the grave a cavity was found, with a diameter of c. $70 \mathrm{~cm}$ and a depth of $65 \mathrm{~cm}$, containing the cranium of a horse, surrounded by extremity bones.

This grave in Leuna is not unique, but comparable finds are known from Slovakia and Hungary from the third to the seventh century. In some cases the graves in question contained human skeletons of Mongolian type or 
objects connected with eastern nomadic cultures. The custom of laying down horses' skulls and feet in the graves already appears in southern Russia in the fourth century AD, perhaps even earlier. Reliable proofs are found in the burial places at Prokovsk and Novogrigorievka in southern Russia. Still further eastwards in the Altai and Yenisei areas crania and feet from horses have been found in graves from the fifth to the thirteenth centuries. ${ }^{9}$ (Figure 4)

\section{Written Testimonies Concerning Horse Sacrifices with Preservation of Skulls, Extremity Bones and Tails}

How are the ritual similarities between the horse offerings in southern Scandinavia and those on the Continent to be explained? In my opinion the people in Scandinavia who performed these sacrifices were influenced by the ideas connected to the horse offerings in the eastern nomadic cultures. Fortunately there are written testimonies of ceremonies where the heads, feet, and tails of sacrificed horses have been preserved. One such early account is given by Ahmad ibn Faḍlān. In 922, during a long journey, he visited different Turkish tribes. He reports the following about one of these tribes, Ghuzzija in what is now Kazachstan:

When a man has died, they dig for him a big grave, in the shape of a house. They approach him, dress him in his garment, his girdle and his bow... In his hand they place a wooden cup, filled with wine. In front of him they place a wooden vessel, filled with wine. They come unto him with all his property and place it at his side in the house and place him there. Then they cover the house and make a kind of cupola made of clay above it. They take his horses, as many as he has, and they kill a hundred or two hundred, all of them. They eat their meat, except the head, feet, hide, and tail. They place these parts on wood, and they say: "These are the horses on which he rides into paradise." And if he has killed people and been a hero, they make wooden sculptures of the same number as those he has killed, and they place them on his grave and say: "These are his servants, who serve him in paradise."

Sometimes they wait a day or two with the slaughter of the animals. Then one of the elderly among their noble men starts to urge them, saying: "I have seen the dead man during sleep, and he said to me: Behold! You can see that my comrades have got ahead of me, and my feet have become weak from following them. I cannot catch up with them, and I have been left behind alone." In this case they take his horses, slaughter them and hang them by the grave.

\footnotetext{
9 Concerning the finds from Central and Southeastern Europe see Klindt-Jensen 1957: 85 f.; Klindt-Jensen 1959: 56.
} 


$$
\begin{aligned}
& 31 .
\end{aligned}
$$

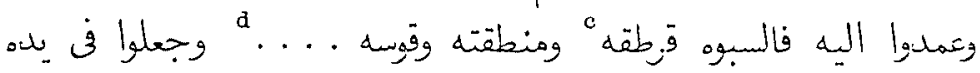

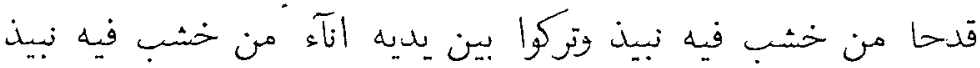

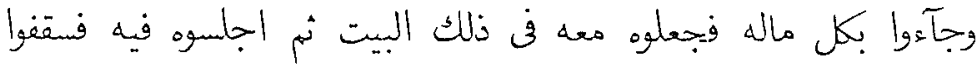

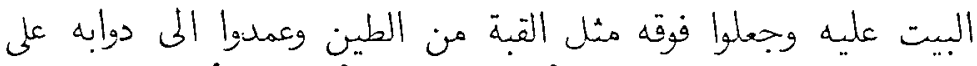

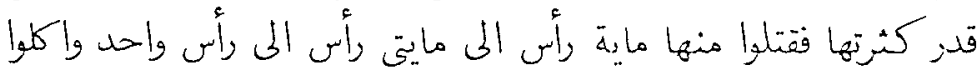

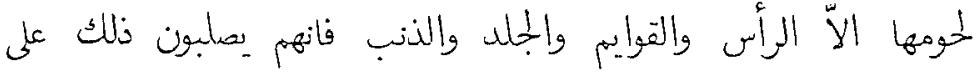

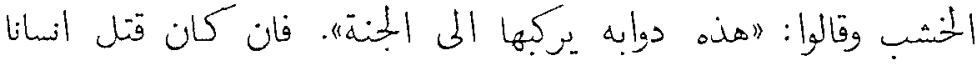

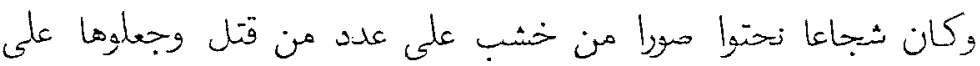

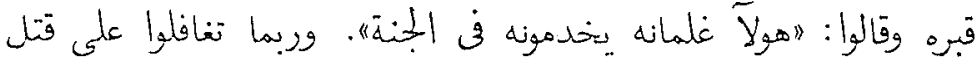

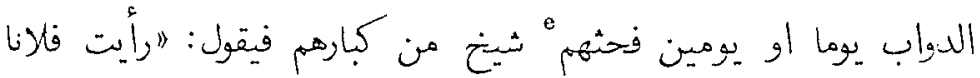

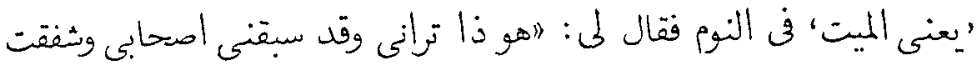

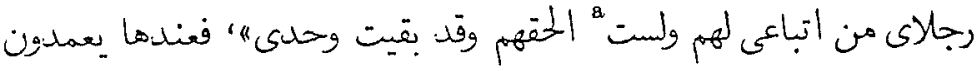

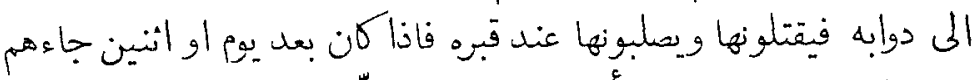

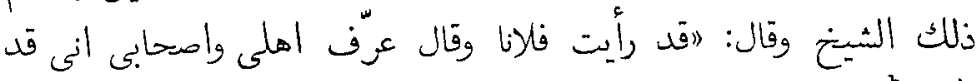

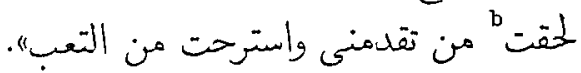

The travel report of Ibn Faḍlān, Ch. 31 (Togan 1939).

And after a day or two the same elderly man comes, saying: "Now I have seen him, and he said: Tell my family and my friends that I have now caught up with those who were ahead of me, and I have been released from my hardship." (Translation from the Arabic by Ulf Görman)

Here Ibn Fadlān describes a horse sacrifice in connection with a funeral where the heads and hides of the horses, together with the accompanying feet and tails, were preserved and placed on a wooden stand close to the grave of the dead man. It is clearly indicated that the horses are supposed to be riding-horses for the dead man on his subsequent journey in the realm of the dead.

This idea is common among many peoples. From a mythological point of view the horse is a symbol of death and of the transition from one existence 
to another. ${ }^{10}$ It is easy to imagine how feet, tail, and head were taken care of and buried in cavities by the grave when the hide had become rotten. This is precisely the way the characteristic remains of horses appear in the grave fields at Prokovsk and Novogrigorievka in southern Russia, at Leuna in central Germany, and probably at two Danish graves from the late Iron Age.

An observation similar to the one made by Ibn Faḍlān is reported by Movsēs Dasxuranç from his visit to the Huns in the Caucasus at the end of the seventh century AD. In the Armenian chronicle Patmuticiwn Aluanic, which I have already mentioned, he describes how the Huns sacrificed horses to the god they called Aspandiat. They made the blood drip over the branches of the oaks, which had been consecrated to Aspandiat, while the hides and heads were hung up in the branches (Dasxuranci 1961: Ch. 41). Among the Ghuzzi-Turks the horse was a grave gift, among the Huns it was a gift for the principal god. In both cases the suspension of the hide together with the attached parts of the body was a central part of the ritual.

Similar horse sacrifices are known, above all from southern Siberia, right up to our time. During the second part of the nineteenth century Wilhelm Radloff was travelling around in the Altai area. Among other things he described the prevalent shamanism, and in that context he gave a detailed account of a horse sacrifice. I shall here give a summary of his description, as it gives a good idea of how these sacrifices were made. It is true that Radloff's report was made 1300 to 1500 years later, but it shows that exactly the same parts of the horse were preserved as in the finds from the fourth to the sixth centuries. Consequently his account may after all give an impression of the ideas behind the sacrifices.

The offering was devoted to the God Ülgön, and in order to deliver the sacrifice, consisting of a blond horse, the shaman, called a kam in Altai, had to force his way through a number of heavens. The greater the power of the shaman, the more heavens he could pass through. The ceremony lasted three nights. On the first evening a suitable place for the sacrifice was elected and the horse was chosen. By means of a birch twig the kam drove the horse's soul out, and riding on a pole in the shape of a goose he pursued the soul and caught it with a snare. After that the offering itself was carried out in the following way:

Wenn nun das Pferd bis tu Tode gequält ist, wird ihm das Fell abgezogen, und

10 Concerning the horse as an animal connected with death and ecstasy see Eliade 1951: $405 \mathrm{f}$. 


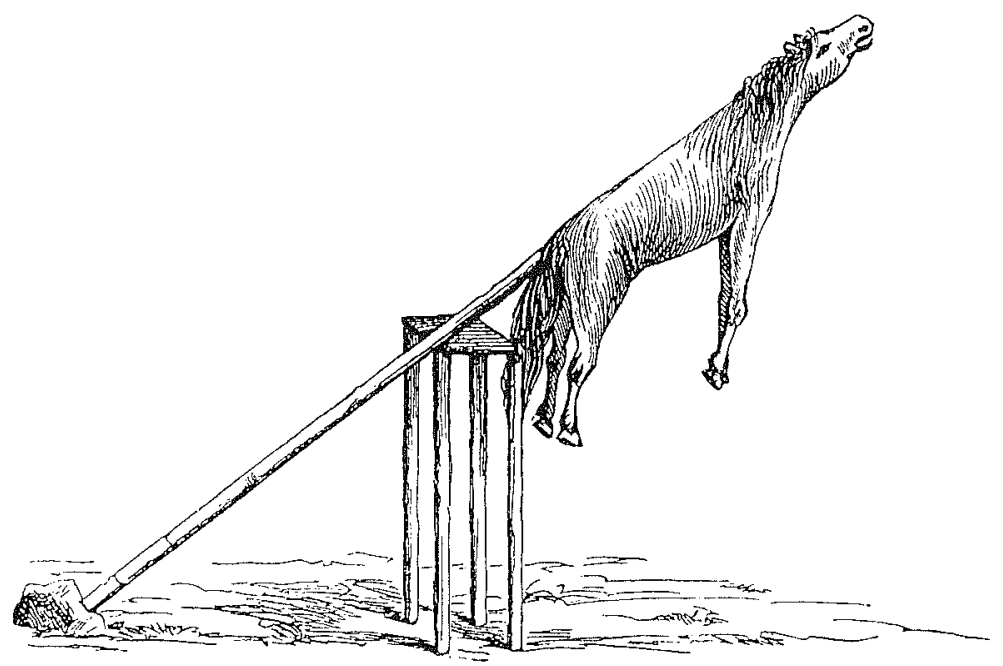

Figure 5. A place of offering with a horse sacrifice among a tribe from Altai (Radloff 1884/2: 18).

zwar so, dass der ganze Schädel und die Füsse bis zu den Knieen in der Haut bleiben. Nur die Zunge wird aus dem Maule herausgerissen. Das Fell wird am Halse und Bauche aufgeschnitten, så dass man den ganzen Körper, ohne die Haut weiter zu beschädigen, herausnehmen kann. Das Fell mit Schädel und Füssen, Baidara genannt, wird nun so auf einer 12-16 Arschine langen Stange (Tükölö) befestigt, dass die Spitze der Stange in die hintere Schädelöffnung gestossen werden kann, die Mitte des Rückens auf der Stange ruht und die vier Beine herabhängen. Dicht vor der Opferstelle wird nun ein kleinerer Pfahl mit einer gabelförmigen Spitze in die Erde gesteckt und über diese die Tükälä so gelegt, dass die Baidara, mit dem Kopfe nach Osten gerichtet, oberhalb des Taskak in der Luft hängt. So ist die Aufstellung der Opfer nur bei den Altajern. (Radloff 1884/2: 26)

Then all the participants ate a sacrificial meal, consisting of the meat of the horse, at which the shaman received the best pieces. Care was taken not to damage the bones, which were placed on a sacrificial table dedicated to Ülgön. On the second evening the kam dressed himself in his shaman dress, called on his guardian spirits and carried out his ecstatic journey through the heavens to Ülgön in order to deliver the sacrifice. On the third evening yet another feast was held, at which libation offerings to the gods were performed. ${ }^{11}$ (Figure 5)

\footnotetext{
11 Concerning the account of this horse sacrifice in Altai see Radloff 1884/2: $20 \mathrm{ff}$. The description of the ceremonies in connection with this offering is classic, and among others it is described by Eliade 1951: $175 \mathrm{ff}$.
} 
A similar description of a horse sacrifice among the Telingites in the central parts of the Altai area can also be found in an account by Wolfgang Amschler, who visited the area as late as 1930 (Amschler 1933).

The early finds of cavities with parts of crania, extremity bones and caudal vertebrae from horses originate from southern Russia and southern Siberia, where instances can already be found in the fourth and fifth centuries AD. It was precisely from this area the conquering expeditions of the Huns towards the central parts of Europe started around 375 AD. According to Klindt-Jensen, the Huns could be the mediators of the horse sacrifice in the specific form we know it from Rislev on Sjælland, Sorte Muld on Bornholm, Skedemosse on Öland, and other places. He mentions the Scuthians and the Sarmatians as other possible mediators as well, but he points out that none of these people seems to have performed horse offerings of this specific type (Klindt-Jensen 1959: 52).

Those who sacrificed the objects in the finds of Sösdala, Fulltofta, and probably even Vennebo, must have had a thorough knowledge of the burial rites of the Huns. The deposits from Sorte Muld, Valmosen, Skedemosse, and other places, give evidence of an equally profound knowledge of the way equestrian nomads from the east carried out their horse sacrifices. But these finds are also proof that people in Scandinavia were not only acquainted with, but also practised the foreign rites reflected in the deposits. This means in turn that they had, at least in part, assimilated the underlying ideas. How did this happen?

\section{Scandinavian Mercenaries in Central and Southern Europe}

The explanation of the evident influences of the Huns in a number of sacrificial finds in Scandinavia from the fourth to the sixth centuries AD is probably to be found in the new élite of warriors which began to emerge during the last century BC. Another explanation could be that Attila's sphere of power extended further than the Baltic.

We know the new class of warriors through their splendid weapon graves as well as the enormous deposits of weapons. These weapon graves occur starting from the late Pre-Roman Iron Age. They become common during the early Roman Iron Age, and they terminate during the late Roman Iron Age. In general they are richly equipped with weapons, horse equipment, gold and imported objects. The imported objects are first of Celtic and later of Roman origin. These burial finds show that a new class of chiefs 
and warriors has developed. It has been concluded from e.g. the equipment in the graves that a small, powerful group of local leaders had developed who gathered younger warriors around themselves. This means that an élite of warriors has distinguished itself from the rest of the population. This is also emphasized by the location of the weapon graves. They are located in secluded places and not in the common big grave fields. The big deposits of weapons also prove the existence of professional, well equipped armies. The many different types of weapons indicate that there were several specialized functions within the armies (Hedeager 1990: $136 \mathrm{ff}$.).

The ancient strongholds in Scandinavia, many of which were in use during 300-500 AD, also give evidence that communities in Scandinavia during this time were politically and militarily well organized (Näsman 1988: 236).

The warrior hierarchy was also the foundation of the archaic state, which, according to the Danish archaeologist Lotte Hedeager, developed in Denmark as early as in 200-375 with its prerequisites in 100-200 and its consolidation in 375-550 (Hedeager 1990).

This élite of warriors, reflected in several ways by the archaeological finds, could gain wealth and honour by serving as mercenaries in the Roman army, and later also by serving in the feared Hunnish army or in its auxiliary troops, constituted by different ethnic groups. In fact we know the name of one of these Scandinavian warrior leaders. In J ordanes' Getica a number of Scandinavian tribes are mentioned, among them the people of Ranrike, whose king Roduulf went to the court of Theoderick, the Gothic king. Roduulf was not the only one to join the Gothic army, but he had many predecessors as well as successors. ${ }^{12}$ Roduulf and his equals, i.e. all those Scandinavians who served as mercenaries on the Continent and who lived in close connection with the Huns, can very well have picked up their life-style, as well as their rites and connected ideas.

I would like to mention another possible explanation for the Hunnish influences on the sacrificial customs in Scandinavia, established from the fourth to the sixth century. As is evident from figure 2, the reign of Attila is considered to have extended to the Baltic. But Priscus, a historian who had himself lived for some time at the court of Attila, states that Attila ruled over "the islands in the Ocean" as well. Thomson, who discusses the reign of Attila, maintains that modern historians are, generally speaking, in agreement that Priscus' statement refers to the islands in the Baltic. Thomson himself argues for this position by referring to the occurrence

12 Concerning Roduulf see Lönnroth 1977: $3 \mathrm{ff}$. 
of Roman solidi on Bornholm, Öland and Gotland. Roman solidi appear on these islands from the beginning of the fifth century $\mathrm{AD}$, and they suddenly disappear at the time of the Byzantine emperor Zeno, who reigned between 474 and $491 \mathrm{AD}$. This fact can, according to Thomson, best be explained if Attila controlled these islands. The empire of the Huns would then have created temporary stability in the area, which promoted trade between the islands and the Continent. Because of the disorder which followed on the death of Attila, this trade would have been cut off (Thompson 1948: $75 \mathrm{f}$.).

Should this interpretation of Priscus' statement be correct, which means that the reign of Attila also included Bornholm, Öland and Gotland, then we would have to reckon with a direct and perhaps even more profound influence from the Huns concerning faith and ritual in some parts of southern Scandinavia during 300-500.

\section{Summary}

In this article I have elucidated the connection between two kinds of sacrificial finds, i.e. horse sacrifices and burial offerings. They are contemporary and they share the same background. They can both be traced back to the Huns. This means that in all probability religious ideas occurred in southern Scandinavia during the fourth to the sixth century which were strongly influenced by the Huns, who were powerful in Central Europe at that time. The explanation of this is probably that some Scandinavians, for instance by serving as mercenaries, had come in contact with the Huns and, at least to some extent, assimilated their ways of thinking and their religious ideas.

By pointing out some written testimonies from the same or later time, I have demonstrated the character of the rites practised by the Huns in connection with horse sacrifices and funerals. The striking similarities between these two types of sacrificial finds in Eastern and Central Europe on one hand, and in southern Scandinavia on the other, make it probable that similar ceremonies were also exercised in southern Scandinavia. Accordingly, I have given an idea of the religious beliefs and rites which may have been the background to the finds of horse sacrifices and the funeral sacrificial finds from the fourth to the sixth centuries in southern Scandinavia. 


\section{References Cited}

\section{Amschler, Wolfgang}

1933 Über die Tieropfer (besonders Pferdeopfer) der Telingiten im Sibirischen Altai. Anthropos. 28: 305-313.

Bóna, István

1979 Die archäologischen Denkmäler der Hunnen und der Hunnenzeit in Ungarn im Spiegel der Internationalen Hunnenforschung. In: Nibelungenlied. Ausstellung zur Erinnerung an die Auffindung der Handschrift A des Nibelungenliedes im Jahre $1779 \mathrm{im}$ Palast zu Hohenems, 14. Sept.-28. Okt. 1979. Bregenz. (Ausstellungskatalog des Vorarlberger Landesmuseums, 86)

Dasxurançi, Movsēs

1961 The history or the Caucasian Albanians. Transl. by C. J. F. Dowsett. London: Oxford University Press. (London oriental series, 8)

Eliade, Mircea

1951 Le Chamanisme et les techniques archaïques de l'extase. Paris: Payot.

Fabech, Charlotte

1987 Krigsbytteoffer - religiøs ceremoni eller politisk manifestation? - en undersøgelse af de sydskandinaviske krigsbytteofferfund og en vurdering af denne offerskiks karakter samt funktion $\mathrm{i}$ yngre romertids og ældre germanertids samfund. Konferensspeciale. Århus: Århus universitet. [Stencil]

1989 Sydskandinaviske offerfund som kilde til jernalderens religion og ideologi. In: Lars Larsson and Bozena Wyszomirska (eds.), Arkeologi och religion; pp. 107117. Lund. (University of Lund. Institute of Archaeology Report Series, 34)

Görman, Marianne

1987 Nordiskt och keltiskt. Sydskandinavisk religion under yngre bronsålder och keltisk järnålder. Lund: Lunds universitet.

\section{Hagberg, Ulf Erik}

1964 Järnålderns offerfynd ur svenskt perspektiv. Tor 10: 222-239.

1967 The Archaeology of Skedemosse; 2 vols. 1: The Excavations and the Finds of an Öland Fen, Sweden. 2: The Votive Deposits in the Skedemosse Fen and their Relation to the Iron-Age Settlement on Öland, Sweden. Stockholm.

Hedeager, Lotte

1990 Danmarks jernalder. Mellem stamme og stat. Århus: Aarhus Universitetsforlag.

Ilkjær, J. and J. Lønstrup

1983 Der Moorfund im Tal der Illerup- $\AA$ bei Skanderborg in Ostjütland (Dänemark). Germania 61: 95-116.

Jensen, Jørgen

1982 The Prehistory of Denmark. London: Methuen.

Jordanes

1882 De origine actibusque getarum (Getica). In: Theodorus Mommsen (ed.), Iordanis Romana et Getica 5/1. Berolini.

Klindt-J ensen, Ole

1957 Bornholm i folkevandringstiden og forudsætningerne i tidlig jernalder. København: Nationalmuseet. (Nationalmuseets Skrifter. Større Beretninger, 2)

1959 Nomadeneinfluss in der späten europäischen Eisenzeit. (150-600 n. Chr.) Folk 1: $51-58$. 


\section{Lönnroth, Erik}

1977 Die Goten in der modernen kritischen Geschichtsauffassung. In: Erik Lönnroth, Scandinavians. Selected Historical Essays; pp. 1-6. Göteborg.

Maenchen-Helfen, Otto

1973 The World of the Huns. Ed. by Max Knight. Berkeley.

\section{Menghin, Wilfried}

1980 Kelten, Römer und Germanen. Archäologie und Geschichte. München: Prestel.

Norberg, $\mathbf{R}$.

1931 Moor- und Depotfunde aus dem 5. Jahrhundert nach Chr. in Schonen. Acta Archaeologica 2: 104-111.

\section{Näsman, Ulf}

1988 Den folkvandringstida ?krisen i Sydskandinavien. In: Ulf Näsman and Jørgen Lund (eds.), Folkevandringstiden i Norden. En krisetid mellem ældre og yngre jernalder. Rapport fra et bebyggelsearkæologisk forskersymposium i Degerhamn, Öland, d. 2.-4. oktober 1985; pp. 227-255. Århus: Aarhus Universitetsforlag.

Radloff, Wilhelm

1884 Aus Sibirien. Lose Blätter aus dem Tagebuche eines reisenden Linguisten. 2 vols. Leipzig: T. O. Weigel.

\section{Strömberg, Märta}

1961 Untersuchungen zur jüngeren Eisenzeit in Schonen. VölkerwanderungszeitWikingerzeit; 2 vols. 1: Textband. 2: Katalog und Tafeln. Lund. (Acta Archaeologica Lundensia. Ser. 1/4)

Thompson, E. A.

1948 A History of Attila and the Huns. Oxford.

Togan, A. Zeki Validi (Hrsg.)

1939 Ibn Fad̆lān's Reisebericht. Leipzig: F. A. Brockhaus. (Abhandlungen für die Kunde des Morgenlandes, 24, 3)

Werner, Joachim

1956 Beiträge zur Archäologie des Attila-Reiches; 2 vols. 1: Textteil. 2: Tafelteil. München. (Bayerische Akademie der Wissenschaften. Phil.-hist. Klasse. Abhandlungen, N. F., 38A-38B)

Worsaae, J. J. A.

1865 Om Slesvigs eller Sønderjyllands Oldtidsminder. En sammenlignende unders $\varnothing-$ gelse. Kjøbenhavn: Gyldendalske Boghandel.

$\emptyset$ rsnes, Mogens

1988 Ejsbøl I — Waffenfunde des 4.-5. Jahrh. nach Chr. København. 